\title{
KELAYAKAN LEMBAR KEGIATAN SISWA TERINTEGRASI \\ NILAI AGAMA PADA MATA PELAJARAN IPA UNTUK MENGEMBANGKAN KARAKTER DISIPLIN
}

\author{
Siti Rosada ${ }^{1}$, Retno Triwoelandari $^{2}$, Irfan Supriatna $^{3}$
}

\begin{abstract}
PGMI, Fakultas Agama Islam, Universitas Ibn Khaldun Bogor
E-mail: sitirosada12@gmail.com ${ }^{1}$,retnotriwoelandari@fai.uikabogor.ac.id ${ }^{2}$,irfansupriatna@unib.ac.id ${ }^{3}$
\end{abstract}

\begin{abstract}
Abstrak
Tujuan penelitian ini adalah untuk mengetahui kelayakan lembar kegiatan siswa terintegrasi nilai agama pada mata pelajaran IPA dalam mengembangkan karakter disiplin. Metode penelitian yang digunakan adalah metode penelitian dan pengembangan (research and development) yang telah dimodifikasi oleh Sukmadinata yang merupakan penyederhanaan dari sepuluh langkah penelitian dan pengembangan Borg and Gall. Metode penelitian ini terdiri dari tiga tahap yaitu pendahuluan, pengembangan, dan pengujian. Teknik pengumpulan data menggunakan angket validasi LKS, lembar observasi karakter disiplin, dan angket respon siswa. Analisis data angket validasi LKS dan angket respon siswa menggunakan perhitungan rata-rata; dan analisis data lembar observasi karakter disiplin menggunakan aplikasi SPSS 20. Hasil analisis angket validasi ahli materi menunjukkan bahwa LKS sangat valid dalam aspek materi serta layak digunakan. Hasil analisis angket validasi ahli bahasa menunjukkan bahwa LKS valid dalam aspek bahasa serta layak digunakan. Hasil analisis angket respon siswa pada uji lapangan menunjukkan bahwa tingkat kemudahan penggunaan LKS sangat kuat. Hasil analisis test-t independent samples test karakter disiplin menunjukkan bahwa terdapat pengaruh penggunan LKS. Berdasarkan hasil analisis data yang telah dilakukan, maka LKS dinyatakan layak digunakan untuk mengembangkan karakter disiplin.
\end{abstract}

Kata kunci: Integrasi agama; karakter disiplin; lembar kegiatan siswa

\begin{abstract}
The purpose of this study to determine the of students activity work sheets integrated with religious values in science subjects the character of discipline. The research method is research and development modified by Sukmadinata consisting of three stages, namely introduction, development, and testing. The data collection techniques used LKS (students'worksheet)
\end{abstract}


validation questionnaire, discipline character observation sheet, and student response questionnaire. The data was analyzed using SPSS 20. The results of the validation questionnaire analysis the experts that the LKS was valid in the material aspects and was suitable for use. The results of linguistic validation questionnaire analysis that the LKS was valid in aspects of the language and was worthy of use. The results of the questionnaire analysis of students' responses indicated that the level of ease of use of LKS was strong. The results of the t-test analysis of the independent samples of discipline indicated that was an influence on the use of LKS. Based on appropriate to be used to develop the character of discipline.

Keywords: Character of discipline; integration of religious value; students worksheet

\section{A. PENDAHULUAN}

Pendidikan yang baik tidak hanya mempersiapkan siswa untuk suatu profesi, tetapi juga mempersiapkan siswa untuk dapat menyelesaikan berbagai masalah yang dihadapinya dalam kehidupan sehari-hari (Susilowati dkk., 2018). Tujuan pendidikan yang hakiki tidak hanya mengembangkan pengetahuan dan keterampilan, tetapi juga mengembangkan karakter siswa. Sebagaimana yang dikemukakan oleh Kumalasari dkk (2019) konsep dasar pendidikan adalah pendidikan nilai yang tujuannya untuk memfasilitasi siswa dalam mengembangkan potensi dasar yang dimiliki dan diorientasikan untuk pembinaan dan pengembangan kepribadian, watak, dan karakter manusia seutuhnya.

Kegiatan pembelajaran membutuhkan bahan ajar dalam menunjang proses kegiatan pembelajaran. Salah satu bahan ajar yang diperlukan dalam kegiatan pembelajaran yaitu lembar kegiatan siswa (LKS). LKS memuat tugas atau langkah kegiatan yang akan dilakukan siswa dalam proses kegiatan pembelajaran. Sebagaimana yang dikemukakan oleh Trianto (dalam Suhenriyadi dkk., 2015) LKS berisi sekumpulan kegiatan mendasar yang dilakukan oleh siswa. Sejalan dengan pendapat Trianto Ernawati dkk (2017) mengemukakan bahwa LKS adalah lembaran-lembaran yang berisi informasi dan intruksi untuk mengerjakan suatu kegiatan belajar sesuai dengan materi pembelajaran guna mencapai tujuan pembelajaran.

Sejatinya, dalam kegiatan pembelajaran siswa tidak hanya mengerjakan berbagai soal yang terdapat di dalam LKS, tetapi juga melakukan berbagai kegiatan yang mendorong siswa aktif seperti kegiatan diskusi dan/praktik. Sebagaimana yang dikemukakan oleh Budisetyawan (dalam Putri dan Widiyatmoko, 2013), LKS merupakan sarana pembelajaran yang dapat digunakan dalam kegiatan eksperimen, demonstrasi, diskusi, dan dapat juga digunakan sebagai tuntunan dalam tugas kulikuler. Namun, faktanya 
adalahLKS yang digunakan dalam proses kegiatan pembelajaran tidak membuat siswa aktif dalam kegiatan pembelajaran. Hal tersebut terjadi karena LKS yang digunakan tidak berisi langkah-langkah kegiatan pembelajaran, melainkan hanya kumpulan soal sehingga siswa hanya mengerjakan soal-soal yang terdapat di dalamnya yang membuat mereka menjadi kurang aktif. Sebagaimana yang dikemukakan oleh Fitri dkk (2017) bahwa LKS yang selama ini digunakan dalam proses pembelajaran merupakan LKS yang hanya memuat soal-soal evaluasi saja, tanpa memuat serangkaian kegiatan pembelajaran yang dilakukan siswa dalam memahami materi pelajaran. Selain itu, LKS yang digunakan di sekolah pada umumnya belum tersusun secara terorganisir dan isinya masih menekankan aspek kognitif saja, tanpa mengembangkan aspek afektif (Frisca dkk., 2014). Aspek afektif yang kurang diperhatikan dalam kegiatan pembelajaran menyebabkan lemahnya karakter yang dimiliki siswa.

Dalam kamus bahasa Indonesia "karakter" adalah tabiat, sifat-sifat kejiwaan, akhlak atau budi pekerti yang membedakan seseorang dengan yang lain, dan watak. Oleh karena itu, karakter identik dengan kepribadian atau akhlak (Margariena dkk., 2016). Karakter disiplin adalah karakter yang patuh dan taat pada ketentuan atau peraturan. Hal ini sejalan dengan pendapat Djojonegoro (Suradi, 2017) yang mengemukakan bahwa disiplin adalah "suatu kondisi yang tercipta dan terbentuk melalui proses dari serangkaian perilaku yang menunjukkan nilai-nilai ketaataan, kesetiaan, keteraturan, dan ketertiban."

Kurang berkembangnya karakter disiplin dibuktikan dengan relatif banyaknya pelanggaran kedisiplinan yang dilakukan oleh siswa, seperti bolos sekolah, terlambat datang ke sekolah, tidak mengumpulkan tugas tepat waktu, dan lain sebagainya. JabarEkspres pernah memuat berita mengenai pelajar yang bolos sekolah. Sebanyak 47 siswa yang terdiri dari siswa sekolah dasar dan menengah terjaring operasi razia pelajar bolos sekolah yang dilakukan oleh dinas pendidikan dan satuan polisi pamong praja (Satpol PP) Kota Cimahi (Jabar Ekspress, 2018). Pengembangan karakter disiplin dapat melalui kegiatan pembelajaran dengan menggunakan LKS yang tersusun dengan baik. Seperti yang dikemukakan oleh Majid (2014) bahwa LKS yang digunakan berfungsi untuk memicu dan membantu siswa melakukan kegiatan belajar dalam rangka menguasai suatu pemahaman, keterampilan, dan/atau sikap serta membantu mengarahkan pembelajaran sehingga lebih efesien dan efektif. LKS juga bertujuan untuk meningkatkan penguasaan materi maupun kemandirian, seperti yang dikemukakan oleh Belawati, yaitu LKS memudahkan siswa berinteraksi dengan materi, meningkatkan penguasaan materi, melatih kemandirian belajar dan memudahkan guru dalam pemberian tugas (Shobirin dkk., 2013). 
LKS yang baik hendaknya terdiri atas format penulisan dan komponen kelayakan yang baik. Format penulisan LKS terdiri atas judul, kompetensi dasar yang akan dicapai, waktu penyelesaian, tujuan penggunaan, alat dan bahan, informasi singkat mengenai materi, langkah kerja dan/tugas yang harus dilakukan, dan penilaian. Adapun komponen kelayakan LKS (Departemen Pendidikan Nasional, 2008) meliputi komponen kelayakan isi, kebahasaan, penyajian, dan kegrafikan. Komponen yang paling utama pada LKS adalah komponen kelayakan isi dan bahasa. LKS merupakan lembaranlembaran yang berisi langkah-langkah maupun berbagai pertanyaan yang ditujukan untuk membimbing siswa dalam melakukan kegiatan pembelajaran sehingga materi (isi) dan bahasa merupakan hal yang sangat penting.

Pengembangan karakter dapat diintegrasikan dalam kegiatan pembelajaran. Adapun integrasi merupakan penyatuan hingga menjadi kesatuan yang utuh atau bulat (Rusdiana, 2014). Upaya integrasi salah satunya dapat dilakukan dengan cara integrasi nilai agama pada mata pelajaran ilmu pengetahuan alam (IPA). IPA merupakan pengetahuan yang sistematis dan tersusun secara teratur yang memiliki unsur produk, proses, sikap, dan aplikasi. Keempat unsur tersebut menekankan bahwa pembelajaran IPA tidak hanya mengembangkan pengetahuan dan keterampilan siswa, tetapi juga mengembangkan sikap siswa.

Terbentuknya sikap sebagai salah satu dimensi pembelajaran IPA dapat diwujudkan melalui integrasi nilai-nilai Islam didalamnya (Yatini \& Triwoelandari, 2018). Nilai agama yang dimasukkan dalam pembelajaran, baik berupa sisipan dalam materi IPA maupun dalam proses kegiatan pembelajaran IPA melalui sisipan pembiasaan nilai agama. Sebagaimana yang dikemukakan oleh Djudin (2012) integrasi IPA dan nilai agama yaitu dengan menyisipkan ayat-ayat Al-Quran (ayat kauniyah) yang relevan dengan topik atau bahasan tertentu dalam IPA. Integrasi yang dimaksud adalah menjadikan Al-Quran dan Sunnah sebagai grand theory pengetahuan (Chaeruddin, 2016). Mengintegrasikan IPA dengan nilai agama merupakan suatu langkah dalam menghasilkan ilmu yang utuh karena IPA sebagai ilmu pengetahuan dan nilai agama sebagai landasan moral maupun akhlak akan membuat siswa tidak hanya berpengetahuan yang luas tetapi juga memiliki akhlak yang baik. Hal ini selaras dengan pendapat Nurhayati (2017) bahwa setelah mengikuti pembelajaran menggunakan LKS IPA berbasis Al quran, siswa memberikan respon positif terhadap penerapan LKS terintegrasi tersebut. Selain itu, pada penelitian yang dilakukan oleh Wulandari dkk (2017) ditemukan bahwa LKS IPA yang mereka teliti layak digunakan untuk mengembangkan karakter siswa. Disamping itu, Sasmito dan Mustadi (2015) mengemukakan bahwa lembar kegiatan peserta didik tematik-integratif berbasis pendidikan karakter layak digunakan untuk mengembangkan karakter kreatif dan kerja keras. 
Penelitian yang dipaparkan dalam artikel ini berbeda dengan penelitian sebelumnya dalam hal LKS pada penelitian ini adalah LKS integrasi pembelajaran IPA dengan nilai agama, serta karakter yang dikembangkan di dalamnya adalah karakter disiplin. Pada LKS ini terdapat nilai-nilai agama yang dapat membuat siswa menyadari pentingnya kedisiplinan dalam kehidupan sehari-hari. Diharapkan dengan menggunakan LKS ini, siswa bisa terbangun kesadarannya akan pentingnya kedisiplinan yang akan memengaruhi karakter disiplin pada diri siswa. Penelitian ini bertujuan untuk mengetahui kelayakan LKS terintegrasi nilai agama untuk mengembangkan karakter disiplin.

\section{B. METODE PENELITIAN}

Metode penelitian yang digunakan yaitu penelitian dan pengembangan atau Research and Development (R\&D). Menurut Sukmadinata (2013), penelitian dan pengembangan merupakan langkah-langkah yang dilakukan dalam tahapan pengembangan suatu produk baru atau penyempurnaan produk yang telah ada yang dapat dipertanggungjawabkan. Subjek penelitian ini yaitu siswa kelas 5 sekolah dasar/madrasah ibtidaiyah berjumlah 146 orang. Adapun teknik pengambilan sampel dilakukan secara random. Teknik pengumpulan data dilakukan menggunakan angket validasi, lembar observasi karakter disiplin, dan angket respon siswa. Tujuan angket respon siswa yaitu untuk mengetahui tingkat presepsi siswa dalam penggunaan LKS (kemudahan menggunakan LKS). Langkah penelitian yang dilakukan pada penelitian ini merujuk pada langkah-langkah yang dikembangkan oleh Sukmadinata yang terdiri atas tiga tahap, yaitu studi pendahuluan, pengembangan, dan pengujian. Berikut ini penjabaran langkah-langkah penelitian yang dilakukan (Sukmadinata, 2013): a) studi pendahuluan atau penelitian pendahuluan dapat dikatakan tahap awal atau persiapan untuk pengembangan yang terdiri atas tiga langkah, yaitu studi pustaka, survei lapangan, dan penyusunan produk; b) pengembangan yang terdiri atas dua langkah, yaitu uji coba terbatas, dan uji coba luas; dan, c) pengujian sebagai tahap akhir yang dilakukan dengan menggunakan metode eksperimental.

Dalam penelitian ini terdapat kriteria yang harus dipenuhi terkait ahli materi maupun bahasa, yaitu mereka harus kompeten di bidangnya masingmasing dan berpengalaman melakukan validasi. Butir penilaian pada angket validasi materi dan bahasa telah sesuai dengan indikator kelayakan LKS. Adapun indikator kelayakan LKS merujuk pada pedoman yang dikeluarkan oleh Departemen Pendidikan Nasional (2008) dan Yasir dkk. (2013).

Kelayakan LKS dapat dilihat dari dua indikator. Pertama, komponen kelayakan isi. Indikator ini terdiri atas kesesuaian dengan standar kompetensi (SK) atau kompetensi isi (KI) dan kompetensi dasar (KD), kesesuaian dengan perkembangan anak, kesesuaian dengan kebutuhan bahan ajar, 
kebenaran substansi materi pembelajaran, manfaat untuk penambahan wawasan, kesesuaian dengan nilai moral dan nilai-nilai sosial, menekankan pada proses untuk menemukan konsep-konsep, dan mendorong siswa terlibat aktif dalam pembelajaran. Kedua, komponen kebahasaan. Indikator ini terdiri atas keterbacaan, kejelasan informasi, kesesuaian dengan kaidah bahasa Indonesia yang baik dan benar, pemanfaatan bahasa secara efektif dan efesien (jelas dan singkat), dan susunan kalimat maupun kosakata yang digunakan baik.

Indikator disiplin yang digunakan pada lembar observasi karakter disiplin merujuk pada Yuliyanto dkk. (2018), diantaranya tepat waktu masuk ke kelas, menggunakan seragam dan atribut secara lengkap, dan berada di dalam kelas selama kegiatan pembelajaran berlangsung. Indikator karakter disiplin dirumuskan dan dikembangkan dalam penelitian ini, yaitu ketaatan dalam menggunakan fasilitas belajar, taat pada waktu kehadiran belajar (tepat waktu masuk kelas), disiplin dalam menggunakan waktu pada kegiatan pembelajaran (menggunakan waktu dengan efektif), taat terhadap penugasan pelajaran, mematuhi peraturan yang ditetapkan dalam kegiatan pembelajaran (ketaatan dalam mengikuti kegiatan pembelajaran), menyelesaikan tugas pada waktunya, mematuhi aturan sekolah, dan mengumpulkan tugas pada waktunya. Data hasil observasi karakter disiplin siswa yang telah diperoleh dianalisis mengunakan aplikasi SPSS 20. Adapun data hasil validasi ahli materi, ahli bahasa, danrespon siswa terhadap LKS dianalisis dengan cara dihitung rata-rata presentasenya.

\section{HASIL DAN PEMBAHASAN Studi Pendahuluan}

Studi pendahuluan terdiri atas tiga tahap, yaitu studi kepustakaan, survei lapangan, dan penyusunan produk. Studi kepustakaan dan survei lapangan dilakukan sebelum penyusun draf produk LKS. Studi kepustakaan dan survei lapangan dilakukan untuk menyeleksi materi yang sesuai maupun memperdalam pemahaman materi atau konsep berkaitan dengan penyusunan LKS. Draf produk yang dikembangkan pada penelitian ini yaitu lembar kegiatan siswa terintegrasi nilai agama pada mata pelajaran IPA untuk mengembangkan karakter disiplin. Draf produk LKS yang telah disusun kemudian divalidasi oleh ahli materi dan ahli bahasa. Validasi dilakukan dengan cara memberikan angket validasi kepada ahli dan LKS yang akan divalidasi. Skala penilaian LKS pada angket validasi yaitu skor 5 (sangat baik), skor 4 (baik), skor 3(cukup), skor 2 (kurang), skor 1 (sangat kurang). 
Tabel 1.Kriteria Interpretasi Skor Kevalidan LKS

\begin{tabular}{cc}
\hline Presentase (\%) & Tingkat Kevalidan \\
\hline $81-100$ & Sangat Valid \\
$61-80$ & Valid \\
$41-60$ & Cukup Valid \\
$21-40$ & Tidak Valid \\
$0-20$ & Sangat Tidak Valid \\
\hline
\end{tabular}

Berdasarkan tingkat kevalidan di atas, maka LKS dinyatakan cukup valid apabila memenuhi kriteria 41\%-60\%. Akan tetapi, LKS membutuhkan revisi (perbaikan) sesuai dengan penilaian yang diberikan oleh validator. Validasi dilakukan oleh satu ahli materi dan satu ahli bahasa. Ahli materi berasal dari ahli materi IPA dan agama. Berikut ini hasil penilaian ahli materi dan bahasa:

Tabel 2. Data Hasil Validasi Ahli Materi

\begin{tabular}{clc}
\hline No & \multicolumn{1}{c}{ Kriteria Penilaian Aspek Kelayakan Isi } & Skor \\
\hline 1 & Materi sesuai dengan kompetensi inti & 4 \\
2 & Materi sesuai dengan kompetensi dasar & 5 \\
3 & Menumbuhkan berpikir kritis & 5 \\
4 & Kesesuaian kegiatan pembelajaran dengan materi & 4 \\
5 & Kebenaran konsep materi pembelajaran & 5 \\
6 & Mendorong rasa ingin tahu & 4 \\
7 & Kedalaman materi & 4 \\
8 & Menumbuhkan sikap peduli terhadap lingkungan sekitar & 4 \\
9 & Langkah kegiatan menuntut siswa menemukan konsep & 4 \\
10 & Pertanyaan mendorong siswa menemukan konsep & 4 \\
11 & Mendorong siswa aktif & 5 \\
\hline & $\quad$ Perolehan skor & 48 \\
& $\quad$ Skor maksimal & 55 \\
\hline
\end{tabular}

Berdasarkan data yang terdapat pada Tabel 2 di atas maka presentase hasil penilaian ahli materi terhadap lembar kegiatan siswa terintegrasi nilai agama pada mata pelajaran IPA untuk mengembangkan karakter disiplin adalah sebagai berikut:

$$
\begin{aligned}
\text { Presentase } & =\frac{\text { Perolehan skor }}{\text { Skor maksimal }} \times 100 \% \\
\text { Presentase } & =\frac{48}{55} \text { X } 100 \% \\
& =87,28 \%
\end{aligned}
$$

Tingkat kevalidan LKS pada aspek materi dapat diketahui berdasarkan data yang terdapat pada Tabel 2 dan hasil perhitungan presentase kevalidan 
LKS; maka LKS dinyatakan sangat valid pada aspek materi dengan skor yang diperoleh $87,28 \%$.

Tabel 3. Data Kuantitatif Hasil Validasi Ahli Bahasa

\begin{tabular}{clc}
\hline No & \multicolumn{1}{c}{ Kriteria Penilaian Aspek Kebahasan } & Skor \\
\hline 1 & Tulisan atau kalimat dapat jelas terbaca & 3 \\
2 & Kalimat dan bahasa mudah dipahami & 3 \\
3 & Ketepatan tata bahasa & 3 \\
4 & Ketepatan ejaan & 3 \\
5 & Kalimat efektif dan efisien & 4 \\
6 & Ketepatan struktur kalimat & 4 \\
7 & Penggunaan kosa kata & 4 \\
\hline \multicolumn{2}{r}{ Perolehan skor } \\
& Skor maksimal & 24 \\
& & 35 \\
\hline
\end{tabular}

Berdasarkan data yang terdapat pada Tabel 3 di atas maka presentase hasil penilaian ahli bahasa terhadap lembar kegiatan siswa terintegrasi nilai agama pada mata pelajaran IPA untuk mengembangkan karakter disiplin adalah sebagai berikut:

$$
\begin{array}{ll}
\text { Presentase } & =\frac{\text { Perolehan skor }}{\text { Skor maksimal }} \\
\text { Presentase } & =\frac{24}{35} \times 100 \% \\
& =68,57 \%
\end{array}
$$

Hasil perhitungan presentase kevalidan LKS pada aspek bahasa mendapat skor $68,57 \%$. Berdasarkan kriteria skor kevalidan LKS pada Tabel 1, LKS sudah memenuhi kriteria kevalidan dan dinyatakan valid. Namun,terdapat beberaparevisi. Revisi dilakukan satu kali dan setelah revisi dilakukan, LKS tidak dilakukan validasi ulang oleh ahli bahasa. Adapun beberapa hal yang direvisi yaitu pada aspek ketepatan tata bahasa dan ketepatan ejaan yang terdapat pada LKS.

\section{Pengembangan}

Pengembangan terdiri atas dua tahap, yaitu uji terbatas dan uji luas. Uji terbatas dilaksanakan pada satu kelompok dengan jumlah siswa 12 orang. Uji luas dilaksanakan pada satu kelompok dengan jumlah siswa lebih banyak yaitu 27 orang. Hasil uji pretest dan posttest karakter disiplin pada uji terbatas dan luas menunjukkan bahwa LKS layak digunakan untuk mengembangkan karakter disiplin. Hal ini dibuktikan dengan hasil analisis uji t paired samples test karakter disiplin yang mendapatkan sig 2-tailed 0,0000 pada tingkat signifikansi (a) $=5 \%$ setara dengan $95 \%$. Hasil sig 2 tailed kurang dari 0,05 . Oleh karena itu, dapat dinyatakan bahwa terdapat 
pengaruh penggunaan LKS terintegrasi nilai agama dalam mengembangkan karakter disiplin siswa.

\section{Pengujian}

Pengujian menggunakan metode eksperimental dengan desain pretest pottest control group desain yang terdiri atas kelompok eksperimen dan kelompok kontrol. Kedua kelompok diberi pretest. Lalu, kelas eksperimen diberi perlakuan dengan menggunakan LKS terintegrasi nilai agama sedangkan pada kelas kontrol tidak. Setelah itu, kedua kelompok diberi posttest. Kelompok eksperimen berjumlah 51 siswa dan kelompok kontrol berjumlah 56 siswa. Angket respon siswa terhadap LKS hanya diberikan kepada kelompok eksperimen karena hanya kelompok eksperimen yang menggunakan LKS terintegrasi nilai agama, sedangkan kelompok kontrol tidak. Item-item pada angket respon siswa terhadap LKS bukan indikator terkait peningkatan disiplin siswa, melainkan digunakan untuk mengetahui tingkat presepsi siswa dalam menggunakan LKS (kemudahan siswa dalam menggunakan LKS). Instrumen angket respon siswa telah divalidasi oleh ahli bahasa sehingga instrumen ini layak untuk digunakan. Berikut ini adalah data hasil penilaian respon siswa terhadap LKS.

Tabel 4.Data Hasil Penilaian Respon Siswa terhadap LKS Terintegrasi Nilai Agama

\begin{tabular}{clc}
\hline No & \multicolumn{1}{c}{ Pertanyaan } & Jumlah Skor \\
\hline 1 & $\begin{array}{l}\text { Lembar kegiatan siswa (LKS) dapat membuat saya semangat dalam } \\
\text { belajar }\end{array}$ & 233 \\
2 & Penggunaan LKS dapat memudahkan saya dalam belajar & 227 \\
3 & Saya dapat memahami materi pelajaran yang ada di dalam LKS & 229 \\
4 & Petunjuk yang digunakan di dalam LKS sangat jelas & 229 \\
5 & Selama menggunakan LKS ini, saya tidak menemukan kata-kata & 217 \\
& yang sulit dipahami & 234 \\
6 & Gambar pada LKS jelas & 243 \\
7 & Jenis huruf, dan ukuran huruf yang terdapat di dalam LKS mudah & 228 \\
& dibaca & 226 \\
8 & Soal-soal yang terdapat pada LKS sangat mudah dipahami & 238 \\
9 & Tampilan LKS ini menarik & 221 \\
10 & Nilai agama yang terdapat pada LKS membuat saya memahami & 226 \\
\hline \multirow{2}{*}{ pentingnya karakter disiplin } & Kegiatan pada LKS membuat saya aktif dalam pembelajaran & 2790 \\
12 & Kalimat yang terdapat pada LKS mudah dipahami & 3240 \\
\hline & $\quad$ Jumlah Skor & \\
\hline
\end{tabular}

Berdasarkan data hasil respon siswa terhadap LKS yang dikembangkan pada Tabel 4, jumlah skor yang didapatkan yaitu 2790. Adapun presentase 
hasil respon siswa terhadap LKS IPA terintegrasi nilai agama yaitu sebagai berikut:

$$
\begin{aligned}
\text { Presentase } & =\frac{\text { Perolehan skor }}{\text { Skor maksimal }} \times 100 \% \\
\text { Presentase } & =\frac{2490}{3240} \times 100 \% \\
& =86,11 \%
\end{aligned}
$$

Hasil analisis respon siswa terhadap LKS terintegrasi nilai agama mendapat persentase $87,28 \%$. Artinya, tingkat kemudahan penggunaan LKS sangat kuat. Pengambilan keputusan tersebut sesuai dengan kriteria interpretasi skor 81\%-100\% termasuk kriteria sangat kuat (Riduwan, 2012).

LKS terintegrasi nilai agama pada mata pelajaran IPA telah divalidasi oleh ahli materi dan ahli bahasa, serta telah diuji coba lapangan. Hasil validasi ahli materi yaitu $87,28 \%$ artinya LKS sangat valid pada aspek materi dan layak untuk digunakan. Pada LKS yang dikembangkan, nilai agama terintegrasi dengan materi pembelajaran IPA. LKS ini memuat konsep islamisasi ilmu yaitu dengan adanya integrasi ayat-ayat Al-Quran yang disesuaikan dengan materi pembelajaran IPA. Konsep islamisasi ilmu pada LKS telah sesuai dengan konsep islamisasi ilmu yang dikembangkan oleh Ismail al-Faruqi. Al-Faruqi mengemukakan bahwa pendekatan yang digunakan dalam Islamisasi ilmu yaitu dengan menuangkan kembali seluruh khazanah pengetahuan barat dalam kerangka Islam melalui penulisan kembali berbagai buku teks berbagai disiplin ilmu dengan wawasan ajaran Islam (Nata, 2018). Integrasi nilai agama dan pembelajaran IPA sangat terlihat pada LKS. Hal tersebut sejalan dengan pendapat Hasanah dan Zuhaida (2018) yang mengemukakan bahwa integrasi agama dan sains dapat terlihat pada komponen pelaksanaan bahan pembelajaran yaitu pada materi ajar dan kegiatan pembelajaran.

Hasil presentase validasi ahli bahasa yaitu $68,57 \%$. Hasil validasi bahasa tersebut menyatakan bahwa LKS valid dan layak untuk digunakan. LKS menggunakan kosa kata maupun kalimat yang mudah dimengerti oleh siswa. Hasil respon siswa terhadap LKS yang dikembangkan mendapat presentase $86,11 \%$ artinya tingkat kemudahan penggunaan LKS sangat kuat. Hasil respon siswa terhadap LKS juga menunjukkan bahwa siswa senang dan mudah menggunakan LKS tersebut sehingga siswa terbantu dalam melaksanakan kegiatan pembelajaran secara lebih aktif dan terarah. Adapun data hasil observasi karakter siswa pada kelompok eksperimen didapatkan perbedaan rata-rata karakter disiplin siswa sebelum dan sesudah menggunakan LKS yaitu 5,31. Sedangkan perbedaan rata-rata karakter disiplin pada kelompok kontrol sebelum dan sesudah yaitu 1,61. Hasil uji pretest-posttest karakter disiplin dianalisis uji t menggunaan SPSS 20. 
Sebelum uji t, data telah diuji normalitas dan homogenitas sebagai syarat untuk melakukan analisis uji t, dan data dinyatakan normal dan homogen. Hasil analisis test $\mathrm{t}$ independent samples test menunjukkan sig-2 tailed 0,000 pada tingkat signifikansi (a) $=5 \%$ setara dengan $95 \%$. Hasil sig 2-tailed kurang dari 0,05 , sehingga dapat disimpulkan bahwa terdapat pengaruh penggunaan LKS terintegrasi nilai agama dalam mengembangkan karakter disiplin siswa.

Berdasarkan hasil analisis validasi ahli materi dan bahasa, analisis uji $\mathrm{t}$ independent samples test, serta analisis hasil respon siswa terhadap lembar kegiatan siswa, LKS layak digunakan untuk mengembangkan karakter disiplin siswa. LKS tersebut membuat pembelajaran menjadi lebih terarah sehingga siswa lebih tertib dalam melaksanakan kegiatan pembelajaran. Nilai agama yang terdapat pada LKS yang dikembangkan dapat mengembangkan karakter siswa karena nilai agama yang terdapat di dalamnya membuat siswa memahami dan menyadari pentingnya kedisiplinan. Hasil penelitian ini, selaras dengan pendapat Djudin (2012) bahwa integrasi IPA dengan nilai agama akan membuat pengajaran lebih bermakna. LKS terintegrasi nilai agama dapat mengembangkan karakter disiplin. Muspiroh (2013) menyatakan integrasi nilai-nilai Islam memiliki tujuan utama agar siswa tidak hanya bertambah pengetahuannya, tetapi juga bertambah kesadaran untuk lebih dekat kepada Allah SWT hingga terjadi perubahan akhlak. Integrasi IPA dan nilai-nilai Islam memberikan kekuatan pada ranah afektif, psikomotorik, dan kognitif. Selain itu, LKS terintegrasi nilai agama tersusun dengan baik sehingga dalam pelaksanaan pembelajaran siswa menjadi disiplin sesuai dengan langkah-langkah kegiatan yang terdapat di dalam LKS. Hasil penelitian ini sejalan dengan hasil penelitian Sasmito dan Mustadi (2015)yaitu LKS yang dapat mengembangkan karakter siswa layak digunakan dalam kegiatan pembelajaran

\section{PENUTUP}

Skor presentase hasil validasi ahli materi terhadap LKS terintegrasi nilai agama pada mata pelajaran IPA dinyatakan sangat valid pada aspek materi. Skor hasil ahli bahasa terhadap LKS terintegrasi nilai agama menyatakan LKS valid pada aspek bahasa. Sementara itu, skor hasil angket respon siswa terhadap LKS terintegrasi nilai agama menunjukkan bahwa tingkat kemudahan penggunaan LKS sangat kuat.Hasil analisis test-t independent samples test karakter disiplin menunjukan bahwa terdapat pengaruh penggunaan LKS terintegrasi nilai agama dalam mengembangkan karakter disiplin. Sedangkan berdasarkan hasil validasi ahli materi, ahli bahasa, hasil respon siswa, dan analisis test-t independent samples test karakter disiplin, LKS terintegrasi nilai agama pada mata pelajaran IPA ini layak digunakan dalam mengembangkan karakter disiplin siswa. 


\section{DAFTAR PUSTAKA}

Chaeruddin, B. (2016). Ilmu-ilmu umum dan ilmu-ilmu keislaman (suatu upaya integrasi). Jurnal Inspiratif Pendidikan, 5(1), 209-222.

Departemen Pendidikan Nasional. (2008). Panduan pengembangan bahan pelajaran.

Djudin, T. (2012). Mempelajari sains, mengimani Sang Pencipta:

Menyisipkan nilai-nilai religius dalam pembelajaran sains. 3(1), 8-14.

Ernawati, A., Ibrahim, M. M., \& Afiif, A. (2017). Pengembangan lembar kerja siswa berbasis multiple intelligences pada pokok bahasan Substansi Genetika kelas XII IPA SMA Negeri 16 Makassar. Jurnal Biotek, 5(2), 1-18.

Fitri, R. A., Noviana, E., \& Fendrik, M. (2017). Pengembangan lembar kerja siswa (LKS) pada mata pelajaran matematika kelas 5 sekolah dasar (penelitian pengembangan dengan materi Volume Kubus dan Balok di SD IT Al-Fityah). Jurnal Online Mahasiswa Fakultas Keguruan Dan Ilmu Pendidikan Universitas Riau, 1-12.

Frisca, C., Rosidin, U., \& Ertikanto, C. (2014). Pengembangan LKS dalam pembelajaran sains bermuatan nilai ketuhanan dan kecintaan terhadap lingkungan. Jurnal Pembelajaran Fisika, 2(2), 77-88.

Hasanah, N., \& Zuhaida, A. (2018). Pengembangan lembar kerja desain madrasah sains integratif: Integrasi sains agama dalam pelaksanaan dan perangkat pembelajaran. Edukasia: Jurnal Pendidikan Islam, 13(1), $155-179$.

Jabar Ekspress. (2018). Razia Pelajar Bolos Sekolah. JabarEkspress.

Kumalasari, I., Luciana, N., \& Wijaya, C. (2019). Integrasi pendidikan nilai dalam membangun karakter siswa di Sekolah Dasar Jampalan Kecamatan Simpang Empat Kabupaten Asahan Provinsi Sumatera Utara. Ristekdik (Jurnal Bimbingan Dan Konseling), 4(1), 1-11.

Majid, A. (2014). Strategi pembelajaran. Bandung: PT Remaja Rosdakarya. Margariena, I. N., Imron, A., \& Burhanuddin. (2016). Mengintegrasikan pendidikan karakter dalam pembelajaran di sekolah dasar. Seminar 
Nasional Pengembangan Profesionalisme Pendidik Untuk Membangun Karakter Anak.

Muspiroh, N. (2013). Integrasi nilai Islam dalam pembelajaran IPA (perspektif pendidikan Islam). Jurnal Pendidikan Islam UIN Sunan Gunung Djati, 28(3), 484-498.

Nata, A. (2018). Islam dan ilmu pengetahuan. Jakarta: Prenadamedia Group. Nurhayati, P. (2017). Pengembangan lembar kerja pembelajaran IPA berbasis Al Quran untuk siswa MI. AL Ibtida: Jurnal Pendidikan Guru MI, 4(1), $61-74$.

Putri, B. K., \& Widiyatmoko, A. (2013). Pengembangan LKS IPA terpadu berbasis inkuiri tema Darah di SMPN 2 Tengaran. Jurnal Pendidikan IPA Indonesia, 2(2), 102-106. https://doi.org/10.15294/jpii.v2i2.2709

Riduwan. (2012). Skala pengukuran variabel-variabel Penelitian. Bandung: ALFABETA.

Rusdiana, A. (2014). Integrasi pendidikan agama Islam dengan sains dan tekonologi. Jurnal Istek, 8(2), 123-143.

Sasmito, L. F., \& Mustadi, A. (2015). Pengembangan lembar kerja peserta didik tematik-integratif berbasis pendidikan karakter pada peserta didik sekolah dasar. Jurnal Pendidikan Karakter, 5(1), 70-81.

Shobirin, M., Subyanto, \& Rusilowati, A. (2013). Pengembangan lembar kerja siswa bahasa Inggris bermuatan nilai pendidikan karakter kelas $\mathrm{V}$ Madrasah Ibtidaiyah Semarang. Journal of Primary Education: JPE, 2(2), 63-70.

Suhenriyadi, A., Suyanto, E., \& Wahyudi, I. (2015). Pengembangan LKS model pembelajaran kooperatif tipe STAD dengan pendekatan saintifik. Jurnal Pembelajaran Fisika, 3(4), 63-71.

Sukmadinata, N. S. (2013). Metode penelitian pendidikan. Bandung: PT Remaja Rosdakarya.

Suradi, S. (2017). Pembentukan karakter siswa melalui penerapan disiplin tata tertib sekolah. Briliant: Jurnal Riset Dan Konseptual, 2(4), 522533. https://doi.org/10.28926/briliant.v2i4.104 
Susilowati, Aswad, M. H., \& Hasri. (2018). Pengembangan lembar kegiatan siswa (LKS) untuk meningkatkan kreativitas belajar matematika siswa kelas VIIA SMPN 1 Kalaena Kecamatan Kalaena Kabupaten Luwu Timur. 11(1), 55-72.

Wulandari, Triwoelandari, R., \& Asmahasanah, S. (2017). Pengembangan model lembar kegiatan siswa (LKS) berbasis inkuiri untuk menumbuhkan karakter rasa ingin tahu Siswa Kelas 5 Di SDIT Kota Bogor. Proceeding 2nd Internasional Multiliteracy Conference and Workshop for Students and Teachers, 421-429.

Yasir, M., Susantini, E., \& Isnawati. (2013). Pengembangan lembar kerja siswa (LKS) berbasis strategi belajar metakognitif untuk meningkatkan hasil belajar siswa pada materi Pewarisan Sifat Manusia. BioEdu, 2(1), 77-83.

Yatini, \& Triwoelandari, R. (2018). Pengaruh metode insersi pada pembelajaran ilmu pengetahuan alam (IPA) terhadap karakter religius siswa kelas 5 SD Al-Azhar Syifa Cibinong. Jurnal Akrab Pekanbaru, $3(3), 75-84$.

Yuliyanto, A., Fadriyah, A., Yeli, K. P., \& Wulandari, H. (2018). Pendekatan saintifik untuk mengembangkan karakter disiplin dan tanggung jawab siswa SD. Metode Didaktik Jurnal Pendidikan Ke-SD-An, 13(2), 87-98. 